\title{
Introduction: Bringing the Study of Work Back to Labor Studies
}

\author{
Tom Juravich \\ Kate Bronfenbrenner
}

L ooking back at our history we cannot ignore how struggles around the changing nature of work itself were formative in the building of the U.S. labor movement. In the early textile mills in Lowell and Lawrence, Massachusetts, New England farm women, and later immigrants from western and central Europe, faced unending work days, dangerous conditions, and abusive supervisors. The rallying cry of the women who struck in Lawrence in 1912 was "Give us bread and roses too." Of course they wanted higher wages, but theirs was no less a fight for dignity and respect-about humanizing their work lives so they might have the time and energy left for family and community.

As Frederick Taylor and Henry Ford pushed the early factory system in the United States to new levels of inhumanity in the 1930s, workers organized in places like Flint, Gary, and Detroit. The CIO and the wave of organizing in auto, steel, and rubber brought important wage increases and the beginning of new employer-based benefits plans. Yet the $\mathrm{CIO}$ also brought important checks to management rights on the shop floor in an effort to restore some semblance of humanity for industrial workers and to make sure that workers had something left at the end of the day to share with their families and friends.

We could explore more contemporary struggles of immigrant workers in meatpacking, hotels, building services, nursing homes, the legions of Wal-Mart workers, or those in more high-tech occupations. And we would discover the same processes at work-that the labor movement is borne from workplace struggles. Up and down the occupational ladder, what workers want is some kind of control on the job, some dignity in their work, some measure of fairness in their workplace, and some chance at a life outside of work.

Labor Studies Journal, Vol. 30, No. 1 (Spring 2005): i-vii. Published for the United Association for Labor Education by the West Virginia University Press, P.O. Box 6295, West Virginia University, Morgantown, WV 26506. (C) 2005, West Virginia University Press. 


\section{Turning Away from Work}

Much has been written about the labor movement in the post-World War II era. For the first time in U.S. history, the labor movement became a legitimate social institution, and a complex infrastructure was developed to resolve labor conflicts as part of the post-war accord between labor and management. Spontaneous strikes and job actions were replaced by labor board charges, formal grievances, and arbitration. As the locus of union activity moved from the shop floor and local unions to union headquarters, pattern bargaining, and contract administration, the labor movement was changing.

Without question this new industrial relations system brought great benefits to a core group of largely white, male, urban, industrial workers. But the labor movement also lost something in the process. Many have written about the costs resulting from labor's bureaucratization, the ensuing servicing model, and the movement away from organizing. At the same time, this postwar paradigm also marked the beginning of labor's move away from work, the labor process, and workplace struggles. For example, as bargaining became more centralized-across local unions and often employers-it increasingly focused on wages and benefits, and less on specific workplace issues.

While we saw tremendous improvement in the economic fortunes of workers during this period, increasing union density and power did not, for the most part, translate into significant institutional changes on the shop floor -no moves to shorten the work day, increase the amount of worker control, or make work less alienating or less physically demanding. The labor movement filed grievances and enforced its complex contracts, but their contracts for the most part did not address the big issues on the shop floor as the labor movement largely ceded control of the shop floor to management. We saw the dramatic consequences of this at Lordstown in the late 1970s as younger workers, horrified with the conditions in the auto plants, struck against their own union. While we did see some efforts in the late 1970s and 1980s at improving the quality of working life, these programs largely transformed into efforts to improve quality and productivity, with few real efforts at job humanization left once the dust settled.

Mirroring what was happening in the labor movement, labor studies and industrial relations also moved away from the shop floor during this time. Our research focused largely on analyzing, evaluating, and determining how these new dispute resolution procedures could be used most effectively. We spent a tremendous amount of energy exploring the NLRB certification process, unfair labor practices, and a variety of dispute resolution practices in the public and private sectors. It is striking to look back through issues of our own Labor Studies Journal to see how few articles appeared during this period 
about work and workplace struggles.

Labor education transformed as well. Breaking with the earlier, more politicized approach of the Highlander Center and others, much of our labor education efforts during this time were designed to teach union leaders and activists how to use these administrative procedures to labor's best advantage. The larger political questions, as well as the smaller more specific questions about work and workplace struggles, largely disappeared.

Given labor's commitment to this proceduralism, and that it was delivering at least economic progress to many America workers, this may have made sense for our field at the time. But, what was happening in the U.S. workplace? Despite our close connections with the labor movement, examining the changing nature of work and its impact on workers and unions was, for the most part, not a central topic of our research and teaching.

\section{Labor, Labor Studies, and the Changing American Workplace}

In the past quarter century we have witnessed a major realignment of the U.S. economy. The nature of corporate ownership has been transformed by globalization, and the employment relationship dramatically altered with the increase of temporary, contingent, and part-time work. As the wreckage of the past three decades suggests, the post-war proceduralism that served labor in the 1950s and 1960s has become ineffectual at best in this new global stage. Despite the Steelworkers, for example, having one of the most advanced dispute resolution systems in the country, it could not save them, first from the concentration of the steel industry, and then from its collapse.

Over the past decade, labor has responded to these changed circumstances with a renewed sense of activism, involving members in building community and strategic campaigns to leverage employers in new and important ways. As we have begun to see in the Labor Studies Journal, it is important that our field not be restricted by the procedural focus of the post-war industrial relations paradigm, and that we document, analyze, and evaluate labor's new activism.

But in addition to these structural changes in the economy, we have witnessed no less dramatic changes inside U.S. workplaces as employees across virtually all sectors of the economy face work reorganization, new technology, and the intensification of work. Americans are working more hours, are reporting more job stress, and are concerned about their jobs and economic security. Like the women at Lawrence or the auto workers on the assembly line, workers today face watershed changes in the U.S. workplace.

Without question, the worst of these workplace changes has been felt more acutely by workers not represented by unions. Yet, what is happening 
in the workplaces across the U.S. is not just a nonunion or low-road phenomenon; it is taking place at the largest and most profitable firms, including those that are unionized. It is becoming clear that holding a union card does not by itself ward off the evils of workplace change. Forced overtime, twelve-hour shifts, seven-day weeks, job combinations, two-tiered benefit structures, cross training, are all, unfortunately, part and parcel of too many union contracts today.

This change is too big to be ignored either by the labor movement or those of us in labor studies and industrial relations. For, if these are the issues that are critical to workers' attitudes about their jobs and their quest for social and economic justice, and unions are not addressing them, then unions are no longer providing the vision that can and will inspire workers to organize. Just as the labor movement had to rethink its commitment to post-war proceduralism, it is now time for labor to return to its roots and engage with its members and its potential members in terms of workplace issues. We saw the effectiveness of this several years ago when the Teamsters focused their campaign against UPS on part-time issues. This was not just a Teamsters issue, nor just a union issue, but one that resonated with the American public, many of whom themselves, or their family and friends, were facing part-time employment.

The recent calls for building a campaign against Wal-Mart hold some of the same promise. The issues emerging from the workers at Wal-Mart such as uncompensated work off the clock, discrimination against women and older workers, lack of benefits and wage increases are issues that many Americans share. This is especially true if the campaign does not degenerate into efforts just to demonize Wal-Mart. If it raises these broad workplace issues, it has real power to connect with a broad swath of workers in the U.S. and around the globe who are watching Wal-Mart degrade their jobs and push down working standards in every community it touches.

This stands in contrast to campaigns such as the current "Voice at Work" campaign and the recent efforts to cast union rights as human rights. As laudatory as their goals are, for most Americans who have not undergone the ravages of trying to organize, these concepts remain abstractions at best. No matter how sophisticated our pitching of these issues it is difficult to see how they will gain much traction unless they are connected to real issues in people's daily lives. This is where connecting with the massive changes that are taking place in U.S. workplaces makes sense-they resonate with the issues that workers face everyday on the job.

We also have a unique opportunity here as researchers and educators. While popular writers such as Barbara Ehrenreich in Nickeled and Dimed and 
some sociologists and economists have begun to explore the contemporary workplace and workplace change, it has largely been undocumented. Our connection to the labor movement provides us with a strong potential to contribute to this debate. Unions can provide access to their members as well as to the firms where they represent workers, and we stand in a unique position to offer a worker's perspective on these issues-which too often is missing from the debate. We can discuss these issues in our labor education classes to fuel our research and in turn use our research findings to inform our labor education programs. It is time to bring the study of work back into labor studies.

\section{Work Time, Stress and Workplace Control}

We held two very spirited workshops on "Bringing the Study of Work Back to Labor Studies" at the 2004 UALE meetings in Chicago. It was refreshing to see how this topic engaged a diverse group of scholars and practitioners from across our field. Ultimately, from these sessions emerged three papers that contribute significantly to our understanding of three important issues in terms of workplace change - work time, stress, and workplace control.

In their paper, Lonnie Golden and Barbara Wiens-Tuers present and analyze extremely important data on mandatory overtime. Since the publication of Juliet Schor's The Overworked American in 1991, and documented repeatedly since, we have been painfully aware that Americans are working more-more than their parents and more than their counterparts around the world. But as a union leader reminded us in one of our workshops in Chicago, it is extremely important to distinguish between voluntary and involuntary overtime. Especially given that many workers have used overtime hours to make up for stagnant wages and insecure employment, he suggested he would "be strung up by his members if he suggested abolishing overtime."

But for the fully one quarter of Americans who Golden and Wiens-Tuers report are required to work overtime, this represents something fundamentally different. They report that mandatory overtime is connected with other lack of controls in the workplace and disproportionately affects foreign-born workers and workers of color. Their findings also suggest that the presence of a union does not dramatically lessen the incidence of mandatory overtime. As the authors suggest, given these numbers, clearly mandatory overtime is an important issue for the labor movement to mobilize around. It affects a large number of workers, union members and non-members alike, and it has significant adverse impacts on workers' lives, both at work and at home.

As he did in his recent The Job Training Charade, Gordon Lafer demolishes another popular myth-that of a nursing shortage. Lafer begins by 
documenting that hospitals and other heath care facilities are indeed facing a serious staffing crisis, particularly in terms of nurses. He goes on to suggest, however, that the quick assumption is often made that this is because of an actual shortage of nursing personnel. Instead, he argues persuasively that there is more than an adequate supply of trained nurses, but that the management practices adopted by the industry, and the working conditions they have created, have forced qualified nurses out of the system. Instead of an actual lack of nurses, these management practices-mandatory overtime, issues of scheduling, stress, staffing, and the lack of the input into decisionmaking - have been depleting the ranks of nursing. Nurses would be ready and available to work if the conditions were right.

It is not only important that we peer behind the conventional wisdom of nursing and health care, but this example reminds us of the importance of working conditions in the choices that workers make. Again, we must remember that nursing is among the professions where unions have been making relatively significant organizing gains, yet to date union contracts have not, for the most part, been able to restrain these management practices.

Finally, Phillip Dearman explores the impact of computerization on social work in Australia. His work reminds us that professional workers are also facing workplace change and that workplace change is not restricted to the United States. He reports that the introduction of a computer system created a contested terrain for workplace control by social workers. It created new tasks and allowed managers to monitor the work of social workers, reducing their workplace control. And, despite its promise of creating efficiencies, it did nothing to alter the workload for social workers. As the labor movement seeks to organize more professional and white collar workers, it must find ways to address the complex issues raised by the introduction of technology. When new technology is introduced, management often suggests it will lighten workload and create efficiencies, but instead it creates new layers of supervisory monitoring, and, in the service professions, new questions about client confidentiality and quality of service.

We hope that you will read and engage with these papers, which represent the beginning of what we hope will be many more discussions of work and the contemporary workplace in the Labor Studies Journal. As the labor movement wrestles with discussion about its future we believe these questions become even more important, because much more than union density, or the structure of the AFL-CIO, the future of the AFL-CIO depends on inspiring both organized and unorganized workers around a common vision and purpose. Somewhere at the core of that vision and purpose will always be what unions can do to give workers some sense of humanity, dignity, and 
power in their workplaces, with something left of themselves to carry home at the end of the day. 
